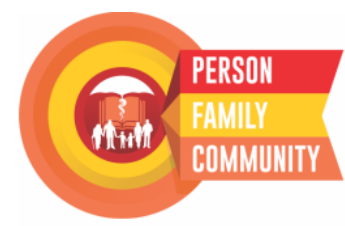

Journal Homepage:

https://jurnal.ugm.ac.id/rpcpe

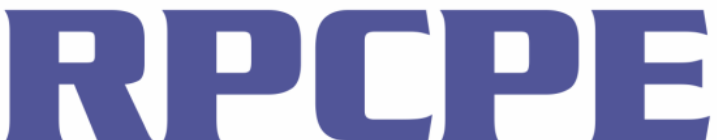

ISSN 2613-943X (print) ISSN 2620-5572 (online)

Review of Primary Care Practice and Education (Kajian Praktik dan Pendidikan Layanan Primer)

\title{
Family Caregiver Phenomenon that Treats Persons with Disabilities Since Birth
}

Halawiah Wia Musi ${ }^{1}$, Mora Claramita ${ }^{2}$, Oryzati Hilman ${ }^{3}$

${ }^{1}$ Primary Health Care Center/Pusat Kesehatan Masyarakat (Puskesmas) Seborokrapyak; Indonesia

${ }^{2}$ Department of Medical, Health Professions Education, and Bioethics; Faculty of Medicine, Public Health and Nursing; Universitas Gadjah Mada; Indonesia

${ }^{3}$ Department of Family Medicine and Public Health; Faculty of Medicine and Health Sciences; Universitas Muhammdiyah Yogyakarta; Indonesia

Corresponding Author:

Halawiah: Primary Health Care Centre/Pusat Kesehatan Masyarakat (Puskesmas) Seborokrapyak, Dusun II, Seborokrapyak, Kec. Banyuurip, Kabupaten Purworejo, Jawa Tengah - 54171, Indonesia

E-mail: halawiahmusi@gmail.com

To cite this article:

Halawiah, Claramita M, Hilman O. Family caregiver phenomenon that treats persons with disabilities since birth. Rev Prim Care Prac and Educ. 2020; 3(2): 14-21.

\begin{abstract}
Background: Disability is a disturbance or limitation of physical activity involving participation restrictions. The disturbance is a problem in the body's function and its structure. Restrictions on physical activity are the difficulties faced in performing tasks or actions, while limiting participation is a problem experienced by individuals in engagement in life situations. Objective: This study aimed to provide an in-depth description of the feelings, explain the obstacles or difficulties experienced and explain the caregiver's expectations of mothers/fathers/brothers in caring for children with disabilities from birth. Method: This study was a qualitative research with a descriptive phenomenology approach. Data collection was conducted through in-depth interviews of family caregivers of persons with disabilities since birth with inclusion and exclusion criteria. The data were analyzed by Colaizzi's method and data triangulation was performed by a coder to maintain data validation. The sample selection was done by purposive sampling. The sample of the study amounted to 17 persons who were family caregivers. Result: The results showed that caregiver phenomenon in caring for persons with disabilities since birth is a burden. Psychological burdens include sadness, disappointment, anger, guilt, depression and ultimately acceptance. Additionally, there are financial burdens, time constraints and social stigma. Conclusions: Caregivers for persons with disabilities since birth experience several burdens, including psychological, physical, financial and social burdens. There is the psychological burden of anger, disappointment, fear, worry, and guilt which many finally can accept. The physical burden of fatigue, lack of sleep, lack of appetite may result in diseases such as gastritis, hypertension, along with muscle and joint disorders. Financial burdens are related to medical expenses, transportation, and daily necessities. The social burden involves stigma, negative labeling and lack of time with other families and communities. It is hoped all caregivers with family and community support can accept and overcome these challenges.
\end{abstract}

Keywords: caregiver, experience, persons with disabilities, stigma, labeling

\section{INTRODUCTION}

Disability is a disturbance or limitation of physical activity involving participation restrictions. The disturbance is a problem in the function of the body and its structure. Restrictions on physical activity are the difficulties faced by individuals in performing tasks or actions while limiting participation is a problem experienced by individuals in engagement in life situations ${ }^{1}$. The number of persons with disabilities is about $15 \%$ of the world's population and $80 \%$ are in developing countries ${ }^{2}$. According to the National Social Economic Survey/Survei Sosial Ekonomi Nasional (Susenas) results in 2012, the number of disabled persons in Indonesia was $6,008,661$ persons $(2.45 \%)^{3}$. The prevalence of persons with disabilities in Purworejo Regency was $0.75 \%$.

Caregivers are someone in the family, whether parents, foster parents, or other family members who help meet the needs of dependent family members ${ }^{5,6}$. The family is the primary caregiver for persons with disabilities. Families for persons with disabilities are the first and the nearest environment to be a major source of support for persons with disabilities ${ }^{6}$. Caregivers serve as emotional support, while caring for patients (bathing, dressing, preparing meals, and administering medications), as well as managing finances and making care decisions ${ }^{7}$.

Problems experienced by family caregivers during caring for persons with disabilities can lead to a variety of phenomena for caregivers and communities. These phenomena can be psychological reactions such as shock, anger, embarrassment, disappointment, stress, and depression along with physical, mental, and financial challenges related to caregiver expectations for children with disabilities from birth, to go beyond the common stigma in the community and ultimately the hope for them 
to be treated humanely and received with sincerity and compassion $^{8,9}$.

\section{Patient's Treatment Plan by Family Physician}

During the first-contact (primary care management) through anamnesis, doctors often obtain information that a caregiver family has a psychological burden of stress, embarrassment, disappointment, worry, inferiority, and confusion. The family physician can assist to provide correct and appropriate information, make two-way communication between doctors and patients to overcome the psychological problems that arise. Additionally, there are physical burdens in the form of fatigue, sleep deprivation, lack of appetite resulting in gastritis, hypertension, and arthritis. Therefore, doctors can provide pharmacological therapy as needed and nonpharmacological therapy for example by the method of Seft (spiritual emotional freedom technique) in order to reduce the physical complaints and common anxieties that arise during the care of persons with disabilities ${ }^{10}$.

Based on the above phenomenon, the researchers aimed to determine the nature of the caregiver family phenomenon that treats persons with disabilities since birth. The main purposes of this study were: (1) To describe these conditions in general regarding caring for a child with a disability from birth; (2) To explain the obstacles or difficulties experienced by a mother/father/brother in caring for persons with disabilities; and (3) To explain the caregiver's expectations for persons with disabilities.

\section{RESEARCH METHODS}

This study was a qualitative research with a descriptive phenomenology approach. Data collection was conducted through in-depth interviews of family caregivers of persons with disabilities since birth in the Banyuurip Sub-district, Purworejo District. Inclusion criteria were: informal caregiver, i.e. in family with children/siblings/persons with a physical, mental or dual disability, age 20 years to 59 years old, domiciled in Banyuurip Subdistrict and willing to become a participant. Exclusion criteria were: formal caregiver, with age less than 20 years and above 59 years. The data were analyzed by Colaizzi's method and data triangulation was performed by a coder to maintain data validation. This research received ethical clearance from the Medical and Health Research Ethics Committee of the Faculty of Medicine, Public Health, and Nursing, Universitas Gadjah Mada. The sample selection was done by purposive sampling. The sample of the study amounted to 17 persons who were family caregivers from birth.

\section{RESULTS}

The results of this study provide an in-depth description of the feelings, inhibitions or difficulties, and expectations of family caregivers while providing care for persons with disabilities from birth. The results are presented below.

Table 1 shows caregiver characteristics of 17 persons, including 6 male and 11 female caregivers, ages between 25-57 years old, with mostly primary and highest secondary education, mostly working as laborers, with a long duration of care for persons with disabilities since birth between 8-30 years.

Table 1. Characteristics of caregivers

\begin{tabular}{|c|c|c|c|c|c|}
\hline Caregiver & $\begin{array}{l}\text { Age } \\
\text { (y.o) }\end{array}$ & Sex & Education & Occupation & $\begin{array}{c}\text { Duration of Caregiving for Persons } \\
\text { with Disabilities from Birth }\end{array}$ \\
\hline 1 & 45 & $\mathrm{~F}$ & Senior High School & Laborers & 22 years \\
\hline 2 & 47 & $\mathrm{~F}$ & Senior High School & Laborers & 15 years \\
\hline 3 & 50 & $\mathrm{~F}$ & Senior High School & Laborers & 26 years \\
\hline 4 & 46 & M & Junior High School & Laborers & 9 years \\
\hline 5 & 50 & M & Senior High School & Farmers & 15 years \\
\hline 6 & 50 & $\mathrm{~F}$ & Elementary School & Farmers & 27 years \\
\hline 7 & 57 & M & Senior High School & Laborers & 11 year's \\
\hline 8 & 56 & M & Senior High School & Private & 21 year's \\
\hline 9 & 50 & M & Junior High School & Private & 12 years \\
\hline 10 & 41 & $\mathrm{~F}$ & Junior High School & Laborers & 8 years \\
\hline 11 & 40 & $\mathrm{~F}$ & Elementary School & Laborers & 30 years \\
\hline 12 & 25 & $\mathrm{~F}$ & Elementary School & Laborers & 25 years \\
\hline 13 & 45 & $\mathrm{~F}$ & Elementary School & Laborers & 10 years \\
\hline 14 & 48 & $\mathrm{~F}$ & Elementary School & Laborers & 19 years \\
\hline 15 & 53 & M & High School & Laborers & 19 years \\
\hline 16 & 42 & $\mathrm{~F}$ & Junior High School & Laborers & 14 years \\
\hline 17 & 40 & $\mathrm{~F}$ & Senior High School & Laborers & 21 years \\
\hline
\end{tabular}

Table 2 shows the characteristics of persons with disabilities age between 8-30 years. Disability type i.e. physical disability, mental impairment, double disability with mild and severe levels and medical history.

From the results of the above studies when related to the grief stage according to Kubler-Ross, each caregiver's results can be described in Table 6 .

The results of this study are related to the description of the feelings of family caregivers who care for people with disabilities from birth, including family caregivers who have children with physical, mental, or multiple disabilities. Table 6 describes the Kubler-Ross Grief Cycle experienced by caregivers who went through the rejection stage by 7 people, the anger stage by 5 people, the depression stage by 6 people, the bargaining stage by 8 people and the stage of acceptance by as many as 15 people. Caregiver feelings can be seen in picture 1 . 
Table 2. Characteristics of persons with disabilities

\begin{tabular}{|c|c|c|c|c|c|c|}
\hline Caregiver & Name & $\begin{array}{l}\text { Age } \\
\text { (y.o.) }\end{array}$ & Disability Type & Level & Diagnosis & Medical history \\
\hline 1 & Miss. G & 22 & Physical & Light & Clubfoot & Unknown \\
\hline 2 & An. T & 15 & Physical & Light & Deaf & Deaf from birth \\
\hline 3 & Miss. $\mathrm{N}$ & 26 & Physical Mental & Heavy & Cerebral palsy and speech impaired & Fainting occurrence \\
\hline 4 & An. AR & 9 & Physical Mental & Light & Down syndrome & Down syndrome \\
\hline 5 & An. SP & 15 & Physical & Light & Hearing and speech impaired & Seizures \\
\hline 6 & Sdr. UD & 27 & Physical & Light & Blind & Blind from birth \\
\hline 7 & Tn. SN & 11 & Physical Mental & Heavy & Cerebral palsy & Premature weight $1400 \mathrm{gr}$ \\
\hline 8 & An. DT & 21 & Physical Mental & Heavy & Cerebral palsy & Seizures \\
\hline 9 & Mrs. BB & 12 & Physical & Light & Aqueduct & Aqueduct from birth \\
\hline 10 & An. Y & 8 & Physical & Light & Blind & Premature weightless $2 \mathrm{~kg}$ \\
\hline 11 & Tn. S & 30 & Physical & Light & Aqueduct & Aqueduct from birth \\
\hline 12 & Tn. SU & 25 & Physical & Light & Aqueduct & Aqueduct from birth \\
\hline 13 & An. US & 10 & Mental & Light & Mentally disabled & Not known \\
\hline 14 & Miss. $\mathrm{H}$ & 19 & Physical & Heavy & Aqueduct & Aqueduct from birth \\
\hline 15 & Tn. PI & 19 & Physical & Heavy & Aqueduct & Premature weight 1700 gr \\
\hline 16 & Mrs. WH & 14 & Physical & Light & Deaf and speech impaired & Deaf and speech impaired from birth \\
\hline 17 & Mrs. SW & 21 & Mental & Heavy & Cerebral palsy & Seizures \\
\hline
\end{tabular}

Table 3. Overview of caregiver feelings who care for persons with disabilities since birth

- Sad to think about the future of children, if the parents are gone there is no futura Sadness is only

Caregiver Code stored alone, considered as a normal part of life, rarely say it to others.

- Sad to see the child's condition, afraid of the child's future. Sometimes feeling offended when people P1 are commenting negatively related to the shortçomings of children, some people even give labels

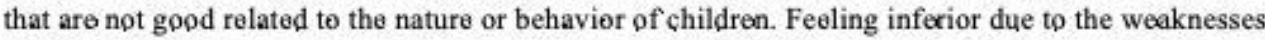
that children have even though they are now starting to accept.

- Feeling they can accept their child's condition that is different from his friends. Trying to sincerely accept the situation. Do not consider children. as a burden.

- Resigned to the child's condition, realizing that children have problems since from the womb. Be patient when children get rejected from friends in the environment because it is considered a contagious disease.

- Thankful siblings, wife, and children can realize the limitations that are owned by younger siblings who have physical disabilities. Fealing sprry for the condition of the younger brother so that he always tries to meet the needs of the younger brother following the message of his late parents.

- Initially folt serry when he realized the child could not see but observing the child's development until he graduated from. high school made him proud and not worried about the child's future. Attitudes of children. who often encourage him to make him. more optimistic. Children are easily organized and directed and rarely cause problems.

- Having felt stressed having to care for a child with Cerebral Palsy due to economic pressures and other household problems, the child is considered as a burden. so that serveral times experiencing despair.

- I had a feeling of disappointment and despair when the child was diagnosed with Cerebral Palsy by a doctor and it was too late t $\rho$ be known. by both parents.

- Not concerned about the condition of the wife who has a physical disability because it does not prevent him from completing tasks in the household.

- Sad with the condition of the child, ostracized by the neighborhood of residence but feel calmer while in the school environment that can accept the child as it is. Children's condition often. gossiped about in the neighborhpod because they cannot seev

- No problem and can accept the condition of disability experienced by the husband felt his soul mate
- Understand and be able t $\rho$ accept the limitations experienced by the husband. The husband can give adviçe that makes her feel calmex.

- Confused, children's develppment is not like children in. general, since experiencing growth retardation

- Feel normal beçause they can accept the child's condition that children have obstacles related to the ability to think. Sincere and can accept children and be proud of children. with varipus limitations they have Trying to fulfill what the child wants because it can make them happy,

- Feeling sad and concerned, if you may choose not to have children. like that, but because of the power of God trying to continue to be able to accept the condition.

- Initially felt disappointed and ashamed of the condition of children, ask what mistakes have been made se that having children like that. Embarrassed when children feel teased by others related to their limitations. Sometimes feel worried about the condition of children who are deaf but because it is God's will then. allow children. to learn independently. Thinking about how the future of a child is supposed to be with a deceased parent.

- Already accustomed to the condition of the child so that they do not feel sad, do not feel difficulty, the important part is that healthy children can make a happy heart even though they have raised their children since they were left by their husbands. Be sincere and accept. 
Table 4. Barriers or difficulties experienced by the caregiver

\begin{tabular}{|c|c|}
\hline Barriers/Difficulties & Caregiver Code \\
\hline $\begin{array}{l}\text { - If the child has difficulties, then they will be helped. But if not, still need to be independent. The } \\
\text { difficulty at the beginning when the child first enters school is when the child adjusts to the school } \\
\text { environment. When. children meet or deal with people who are new to them. }\end{array}$ & P1 \\
\hline $\begin{array}{l}\text { - Feeling difficult to face children but trying to be patient. Husbands are considered less able to work } \\
\text { with and are less able to provide support to children, often even angry because children are difficult } \\
\text { to teach. }\end{array}$ & $\mathrm{P} 2$ \\
\hline $\begin{array}{l}\text { - Cannot be independent, for personal needs, children still need help, to eat, take a showex, urinate, etc. } \\
\text { Difficult to communicate and receive information. If there are guests, they often disturb the } \\
\text { conversations. }\end{array}$ & P3 \\
\hline $\begin{array}{l}\text { - When receiving lessons, children are less able to respond quickly despite high spirits. When a child is } \\
\text { rejected by the environment, the caregiver feels uncomfortable but tries to ignore the situation. }\end{array}$ & P4 \\
\hline $\begin{array}{l}\text { - Feeling difficult when I want to give help to my sister because sometimes the economic conditions } \\
\text { are in poor condition. }\end{array}$ & P5 \\
\hline $\begin{array}{l}\text { Difficulties are felt when the child is still in school at SLB, taking the child to school on a bicycle } \\
\text { which is about } 15 \mathrm{~km} \text {. from his home, many joys, and sorrow during the journeys. After a child has } \\
\text { graduated from senipr high school, he feels more relieved because he can be independent and instead } \\
\text { becomes a music aid teacher at school. }\end{array}$ & P6 \\
\hline $\begin{array}{l}\text { - Support from extended families does not exist because of economic limitations. The emotional } \\
\text { condition of children is less stable, so it is difficult to control, where children often scream and ask } \\
\text { for food so that sometimes parents get emotionally provoked. }\end{array}$ & P7 \\
\hline $\begin{array}{l}\text { - Not yet able to be independent to take care of his personal needs, but for some simple tasks } \\
\text { sometimes want to help. When the head hurts, children often beat the head and emotional conditions } \\
\text { become unstable, so it is difficult to control. }\end{array}$ & P8 \\
\hline $\begin{array}{l}\text { - For hard work, the wife cannot do it alone, but it is anticipated by asking someone else's help to } \\
\text { complete it. }\end{array}$ & P9 \\
\hline $\begin{array}{l}\text { - Children. are socializing less and rarely play with neighbors because they are often. ridiculed and } \\
\text { treated less well by their friends. When children are top active, children are difficult to control, } \\
\text { sometimes raging when desires are not met. }\end{array}$ & P10 \\
\hline $\begin{array}{l}\text { - The husband is independent and can work, does not feel experiencing pbstacles when living together } \\
\text { with her husband. }\end{array}$ & P11 \\
\hline $\begin{array}{l}\text { - Feeling that you have never experienced significant difficulties during the marriage, if there are } \\
\text { problems then they are faced together and work togethex. }\end{array}$ & P12 \\
\hline 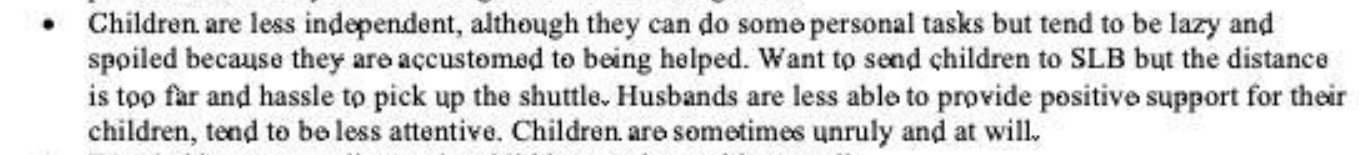 & P13 \\
\hline - Worried because until now the child has not been able to walk. & P14 \\
\hline $\begin{array}{l}\text { - Worried because the child cannot walk. Thinking about the child's future if both parents are gone and } \\
\text { the child has not been able to walk, who will care for him later. }\end{array}$ & P15 \\
\hline $\begin{array}{l}\text { The child cannot speak yet, but for physical difficulties, there is no one for the child who can help if } \\
\text { there is need to do something. }\end{array}$ & P16 \\
\hline $\begin{array}{l}\text { - Obstacles experienced when caring for children, especially when the child has difficulty sleeping and } \\
\text { defecating, so they must be stimulated with fruits that can make defecating happen more regularly } \\
\text { and smoothly. }\end{array}$ & P17 \\
\hline
\end{tabular}


Table 5. Caregiver expectation of persons with disabilities

- The hope is that children can walk like other children, can be more mature and more accepting of the situation.

- She can send children to graduate from Senior High School. Her husband is more able to accept

P1 and motivate children to progress. Children do not give up easily when they fail and are not ashamed of their limitations.

- She can understand the limitations of children and does not have much hope, that her children can. be independent enough.

- She can be independent and hope their children are normal. Want to have normal children like other pepple's children. Even though they cannot go to schopl until the high school level, they hope that children can have special skills directed by their abilities.

- Hoping his siblings are given health by Ged so that they can continue to establish communication and continue to help younger siblings who have limitations.

- Proud of the achievements of children and hopes that children can. work to make their own money.

- The child can be independent to take care of persenal needs despite realizing the child has a disability so they cannot function like other normal peppla

- The child can be independent and normal, can be independent to take care of their personal needs eren thpugh they realize the child has a disability $s \rho$ that they cannot function like other normal people.

- Provide support to the husband.

- Hoping his child be normal, not falling far behind his friends because the child does not experience disabilities and has enthusiasm. for learning and can be independent. She hopes that her child whe has limitations gets more attention from the environment/village government.

- Already satisfied and happy with their current livelihood and does not want anything more from. the husband.

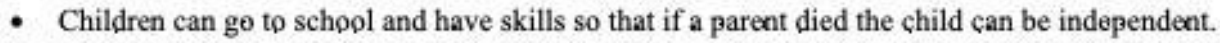

- Hope that many children will help because there are many siblings. Hoping children have gopd temperament and can think of other families, not just thinking about themselves because people live together helping each other.

- Hoping one day the child will be able to walk, because if at home the child sometimes exercises standing alona Children can go to scheol to the highest level of education because children only experience physical obstacles, while can still follow school lessons.

- Children can be independent and if parents have died, children can find their own money

- Realizing that hope for recovery seems to be gone, as long as the child is healthy and not fussy, that's enough.

Table 6. Kubler-Ross grief cycle

\begin{tabular}{|c|c|c|c|c|c|c|}
\hline Caregiver & $\begin{array}{l}\text { Duration } \\
\text { Caring for }\end{array}$ & Denial & Anger & Depressipn & Bargaining & Acceptance \\
\hline 1 & 22 years & Afraid & Worried & Sad & How is the future & It's considered normal \\
\hline 2 & 15 years & Desperate, offended & Impatient, Worried & Sad & $\begin{array}{l}\text { I did not think that } \\
\text { my child would be } \\
\text { deaf }\end{array}$ & $\begin{array}{l}\text { Accept destiny, } \\
\text { grateful }\end{array}$ \\
\hline 3 & 26 years & - & - & - & - & $\begin{array}{l}\text { Accept, sincere, not } \\
\text { burdened }\end{array}$ \\
\hline 4 & 9 years & - & - & - & - & Surrender, be patient \\
\hline 5 & 15 years & - & - & - & - & Grateful, feel sorry \\
\hline 6 & 27 years & Pity & - & - & $\begin{array}{l}\text { The friends can see, } \\
\text { my child cannot see }\end{array}$ & Proud \\
\hline 7 & 11 years & Stress & - & Desperate & - & Accept \\
\hline 8 & 21 years & Disappointed & Cry & Desperate & $\begin{array}{l}\text { My child is like this } \\
\text { due to fate }\end{array}$ & - \\
\hline 9 & 12 years & - & - & - & - & Destiny, accept \\
\hline 10 & 8 years & $\begin{array}{l}\text { Excommunicated, } \\
\text { stigma }\end{array}$ & - & Sad & - & Accept \\
\hline 11 & 30 years & & - & - & - & Accept, destiny \\
\hline 12 & 25 years & & - & - & - & Sincere, accept \\
\hline 13 & 10 years & Confused & - & - & $\begin{array}{l}\text { Child development } \\
\text { is incompatible } \\
\text { with children in } \\
\text { general }\end{array}$ & - \\
\hline 14 & 19 years & - & Worried & - & - & Accept, sincere, proud \\
\hline 15 & 19 years & Concerned & Worried & Sad & $\begin{array}{l}\text { Regret, do not want } \\
\text { to have children. } \\
\text { like this. }\end{array}$ & God's will \\
\hline 16 & 14 years & $\begin{array}{l}\text { Embarrassed, } \\
\text { disappointed }\end{array}$ & Worried & - & $\begin{array}{l}\text { Wonder what } \\
\text { mistakes were done } \\
\text { to have a child like } \\
\text { this. }\end{array}$ & Destiny \\
\hline 17 & 21 years & - & Worried & - & - & Adaptation, accept \\
\hline \multicolumn{2}{|c|}{ Number of Participants } & 9 & 7 & 6 & 7 & 16 \\
\hline
\end{tabular}




\section{Caregiver Fatigue}

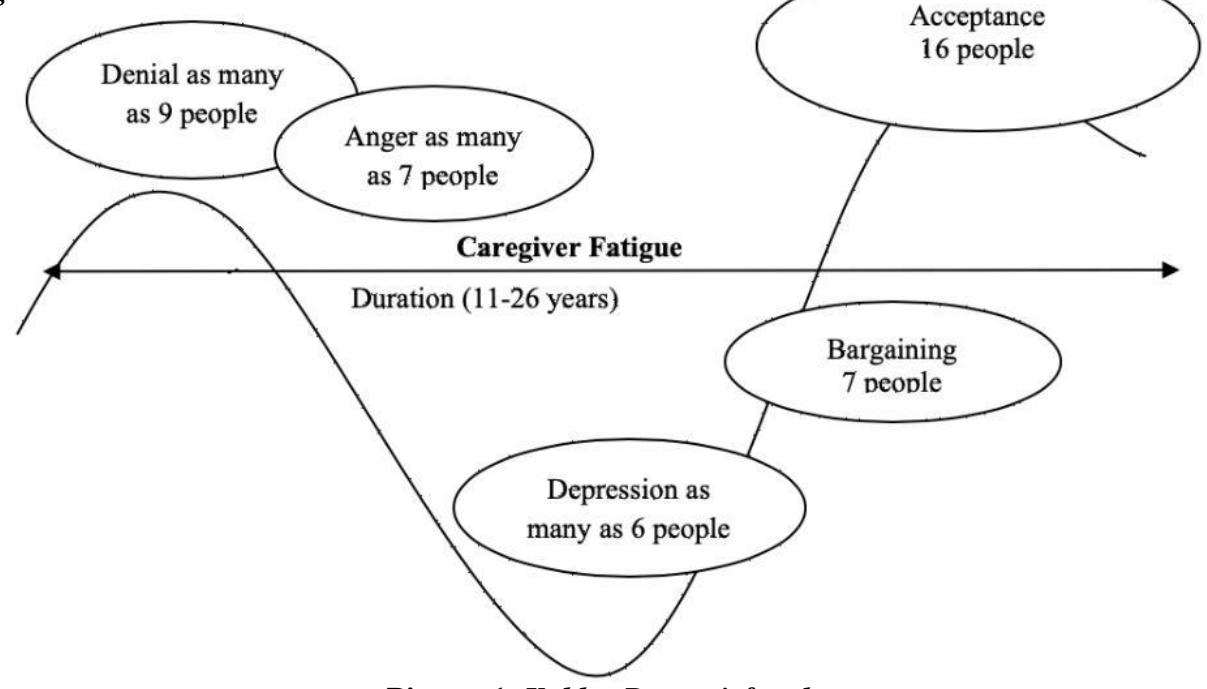

Picture 1. Kubler-Ross grief cycles

\section{DISCUSSION}

The results related to the description of the feelings of the family caregiver who care for people with disabilities from birth are depicted in Table 6 . The caregivers describe the stage of acceptance as grateful for the time together, destiny, surrender, or not a problem. The grief theory explains that not everyone can go through all stages of the Kubler-Ross Grief Cycle. Some stages may be skipped completely, some will experience a different sequence of stages, while some will experience a return to previous stages and others may be trapped at one stage. The results of this study are consistent with studies that found that it may take a long time for caregivers to adapt to children with disabilities and return to a good family situation?

The results of this study explain that family caregivers experience obstacles, both in sharing the barriers of persons with disabilities from birth and their own barriers as caregivers. Barriers for persons with disabilities are:

\section{Cannot be Independent}

Based on the results of this study, it was found that caregivers did not experience insurmountable obstacles but some caregivers had difficulty in caring for and assisting persons with disabilities, namely difficulties related to children being unable to be independent to take care of personal needs such as eating, bathing, defecating, urinating, etc. The results of this study are in line with other studies that found that the duty of a caregiver has challenges to unite the family itself ${ }^{5}$. This finding matches with other studies which indicate that the experience of parents in caring for children has different levels, depending on the type of disability and severity of disability, emotional support, and family empathy, for example, family support, and community support such as neighbors, and friends can provide a sense of peace and acceptance of the heart ${ }^{11}$.

\section{Difficulties for School Access}

The results of this study found that caregivers had some early difficulty when the child is entering school, i.e., children find it difficult to adjust to the new social and physical environment so that caregivers experience fatigue. This is consistent with other studies that showed caregivers with people with disabilities experience physical, psychological, and social challenges in the community such as fatigue due to additional duties during parenting, emotional distress, interpersonal difficulties, financial problems, and adverse social consequences such as social isolation ${ }^{12}$.

\section{Organ Malfunctioning}

Based on the results of the study, many caregivers have fears about the future related to the physical disabilities experienced by persons with disabilities such as not able to walk, cannot see, and cannot hear and this forces parents to adjust more than parents who do not have children with disabilities ${ }^{13}$. Recently, a United Nations convention on persons with disabilities provides some protections including inclusive education for all children and compassionate labeling language that asked the society to respect people who are handicapped by referring to them as persons with disabilities instead of disabled people, which is called, the universal use of 'People First' labels ${ }^{14}$.

In addition to the barriers experienced by persons with disabilities from birth, caregiver barriers involve several burdens namely psychological, financial, physical and social burdens in caring for and assisting persons with disabilities from birth.

\section{(1) Financial Burden}

The results of this study indicate that assisting and caring for family members with disabilities requires huge costs for care, education, and daily needs. Because the economic condition is sometimes in a bad situation, caregivers often experience a feeling of stress and fatigue, lack of sleep and lack of appetite, which can trigger gastritis, hypertension, and arthritis. The results of this study are consistent with the research that found one of the caregiver's physical impacts is fatigue. Fatigue in the form of back pain or muscle pain is often felt by caregivers in America in caring for people with disabilities in old age ${ }^{15}$. The musculoskeletal impact is a common physical complaint among caregivers. Other research supports that there are some changes in caregivers such as physical, psychological, social and spiritual changes ${ }^{16}$. 


\section{(2) Psychological Burden}

The results of the study explained that caregiver's psychological reactions include forms of anger, negative emotions, such as shame, disappointment, worry, sadness and even difficulty in enduring the reactions of people with disabilities by hitting parents or hitting themselves if their desires are not immediately responded by parents, which are heavy psychological burdens for the family caregiver. Negative emotions and anger of parents often arise because of the physical burden of fatigue, muscle disorders, from caring all day and night for their children. Parents feel stressed facing children with emotional conditions involving these challenges. These incidents can occur repeatedly during caring for and assisting persons with disabilities from birth. This finding is consistent with research in America that showed the burden of caregivers is very heavy, especially psychological and physical burdens related to caring for people with disabilities ${ }^{16}$. These challenging incidents require family coping in the form of a sense of acceptance, patience, sincerity, and assistance from community and the family doctor to deal with psychological problems.

Another event which is common is when a child is too active and becomes difficult to control, the they will sometimes go berserk when their desires are not fulfilled. These conditions cause caregivers negative stress from the challenging situation. The results of this study fit the theory that self-control is strongly influenced by one's emotional state ${ }^{17}$.

\section{(3) Social Relations}

According to caregivers, children with disabilities are less able to socialize and rarely play with neighbors. Stigma and maltreatment from neighbors make children tend to avoid social interactions ${ }^{17}$. The results of this study are in line with previous studies that showed the family is the first and also the closest environment which is the main source of support for people with disabilities ${ }^{6}$.

\section{(4) There are No Obstacles}

Generally, caregivers experience difficulties and challenges in accompanying children or family members who have disabilities, but some caregivers do not experience obstacles. These family caregivers use two-way communication in discussions, sharing tasks, and overcome deficiencies, which can be covered by asking for help with others and taking responsibility for their tasks. This is reinforced by the communication theory of health workers and patients ${ }^{18}$.

The results of this study also explain the expectations of caregivers while caring for people with disabilities from birth. Some caregivers hope their children will recover and return to normal, and many caregivers expect children to become independent. Accordingly, the caregiver's expectations in caring for and assisting persons with disabilities are discussed below:

\section{(a) Organs can Function}

Based on research findings, caregivers who have families with physical disabilities still have the hope that their children can walk. This hope remains because the child goes through a period of growth. The research findings support the initiatives in the United Nations convention for people with disabilities to provide rehabilitative services and adaptive technologies that can assist them in gaining a more functional life ${ }^{14}$.

\section{(b) Have a Good Education}

Many caregivers also hope to send their children to high school graduation. Other caregivers hope that children can attend the highest level of education. The United Nations conventions on people with disabilities ensures that education must be easy to reach regardless of the status of each child $^{19}$. In America, the term for this inclusive approach is the guarantee of FAPE or 'Free and Appropriate Education' for all children.

\section{(c) Family/Government Support}

Caregiver burdens include both the social and financial burdens. Caregiver financial burdens are in the form of medical expenses, physiotherapy, and transportation, while the social burden is often in the form of lost time away from family and community. These conditions mean caregivers need additional support in the form of motivation, information, solutions, and support from family, neighbors, friends, government, and social institutions. Many types of supports can be provided to reduce the family burdens. The caregiver needs family support in the form of emotional, physical, instrumental, and information supports ${ }^{19}$. Government support is also needed by people with disabilities and caregivers since many caregivers revealed that their children do not get help from the village government. Government support for children with disabilities is currently included in the National Health Insurance/Jaminan Kesehatan Nasional (JKN) program, which ensures a free education, improved access and facilities, and infrastructure ${ }^{20}$.

\section{CONCLUSIONS}

From the results of this study, it can be concluded that caregivers who care for people with disabilities from birth face many burdens, namely psychological, physical, financial, and social burdens. Psychological burdens are often in the form of anger, disappointment, fear, worry, and guilt but many finally can accept these challenges. The physical burdens include fatigue, lack of sleep, lack of appetite, which can result in diseases such as gastritis, hypertension, muscle disorders and joint pain. Financial burdens are related to medical expenses, transportation, and the cost of providing for daily needs. The social burdens involve various forms of stigma and negative labeling as well as lack of quality time spent with their families and communities. Besides meeting these challenges, caregivers must be able to make psychological adjustments that are influenced by several factors, namely the characteristics of children in the form of age, type of mild and severe disability, dual diagnoses, and history of illness or childbirth and the characteristics of the caregiver, namely duration of care, sex, education and age of caregiver.

\section{Acknowledgments}

We would like to thank all family caregivers in Banyuurip Subdistrict Purworejo who have agreed to become 
respondents in this study.

\section{Ethical Approval and Informed Consent}

This research has been approved by the Medical and Health Research Ethics Committee (MHREC) from the Faculty of Medicine, Public Health, and Nursing, Universitas Gajah Mada with reference number KE/FK/1281/EC/2017.

\section{Funding}

Self-funding

\section{Availability of Data and Material.}

Data and material can be accessed via the corresponding author

\section{Conflict of Interest}

None.

\section{REFERENCES}

1. World Health Organization. World Report on Disability. Geneva: World Health Organization; 2011. Available from: https://www.who. int/disabilities/world_report/ 2011/report.pdf

2. World Health Organization. WHOQOL: Measuring Quality of Life. Geneva: World Health Organization; 2004. Available from: https:// www.who.int/healthinfo/survey/whoqol-qualityoflife/en/

3. Central Statistics Agency. National socioeconomic survey 2012. Jakarta: Central Statistics Agency; 2012.

4. Social Services of Purworejo Regency. Data of people with social welfare problems Purworejo Regency 2016. Purworejo: Social Services of Purworejo Regency; 2016.

5. Social Griffin EM. A First Look at Communication Theory. 5th ed. New York: McGraw-Hill; 2003.

6. Somantri TS. Psychology of the Extraordinary Child. Bandung: Refika Aditama; 2007.

7. Kung WW. The illness, stigma, culture, or immigration?: burdens on Chinese American caregivers of patients with schizophrenia. Families in Society. 2003; 84(4): 547-57.

8. Kübler-Ross E. On Death and Dying. London: Routledge; 1969.
9. Zainuddin AF. Spiritual Emotional Freedom technique (S-EFT). Jakarta: Afzan Publishing; 2009.

10. Sukmarini N. Optimizing the role of caregivers in the management of schizophrenia. Bandung: Psychiatric Magazine. 2009; 42(1): 58-61.

11. Son AHK. Social insurance programs in South Korea and Taiwan: a historical overview. Uppsala: Department of Economic History Uppsala Universitet; 2002

12. Gupta A, Singhal N. Positive perceptions in parents of children with disabilities. Asia Pacific Disability Rehabilitation Journal. 2004; 15(1): 22-35.

13. Marrón EM, Redolar-Ripol D, Boixadós M, Nieto R, Guillamón N, Hernández E, Gómez B. Burden on caregivers of children with cerebral palsy: predictors and related factors. Universitas Psychologica. 2013; 12(3): 767-77.

14. Wardhani MK, Rahayu MS, Roasiana D. The relationship between "personal adjustment" with acceptance of children with special needs in RSUD X. Proceeding of SNaPP: Sosial, Ekonomi dan Humaniora. 2012; 3(1): 49-54.

15. Republic of Indonesia. Act number 8 of 2016 regarding persons with disabilities. Republic of Indonesia State Gazette of 2016 Number 69. Jakarta: State Secretariat; 2016.

16. Beanlands H, Horsburgh ME, Fox S, Howe A. Caregiving by family and friends of adults receiving dialysis. Nephrology Nursing Journal. 2005; 32(6): 621-31.

17. Goleman D. Emotional Intelligence (translation). Jakarta: Gramedia Pustaka Utama; 2000.

18. Hurlock EB. Child Development. New York: McGraw-Hill; 1999.

19. Claramita M, Susilo AP, Rosenbaum M, van Dalen J. Communication of health workers and patients in the context of Southeast Asian culture. Jakarta: EGC; 2016.

20. Nuraenah N, Mustikasari M, Putri YSE. Relationship of family support to the burden of family caring for family members with a history of violent behavior at the Klender Islamic Mental Hospital, East Jakarta. Journal of Nursing Mental. 2014; 2(1): 41-50. 